DOI https://doi.org/10.30525/978-9934-588-90-7-48

\title{
ОБРАЗ «ТИХОГО СВІТУ» В ПОЕЗІЇ ТАРАСА ШЕВЧЕНКА: ПРИХОВАНІ СЕНСИ
}

\author{
Ткаченко О. П. \\ кандидат філологічних наук, \\ доиент кафедри історії української літератури, \\ теорії літератури та літературної творчості \\ Київський національний університет імені Тараса Шевченка \\ м. Київ, Украӥна
}

У ліриці Тараса Шевченка неодноразово натрапляємо на образ «тихого світу». Особлива креаційна сила цього образу дозволяла Шевченкові вписувати його в різні контексти та надавати складних, неочевидних сенсів.

Походить цей образ 3 християнської гімнографії. «Світе тихий» один з найдавніших християнських гімнів, автор і час створення якого до кінця не з'ясовані. Вірогідно, що текст міг бути написаний священомучеником Афіногеном (4 ст.) або ж патріархом Софронісм Єрусалимським (7 ст.). Читається цей короткий гімн на вечірні і входить до чину благословення західного світла. Однак це не лише подяка віруючих за прожитий день: поклоніння природному світлу, як це було в язичників, тут замінене на поклоніння світлу духовному - Ісусові Христу. Всього лише в кількох рядках авторові гімну вдається розгорнути величну алегорію христологічного змісту: лагідне вечірне світло від яскравого й потужного сонця співвідноситься із Христом образом Бога Отця і виявом Його святої слави: «Свете тихий, Святыя славы Бессмертного Отца Небеснаго, Святаго, Блаженнаго, Іисусе Христе!». Богословський сенс алегорії в тому, що через Христа людство має можливість пізнати Отця Небесного так само, як силу й красу сліпучого сонця - через споглядання ласкавого призахідного світла.

Пов'язаність Христа зі світлом є загальним місцем у християнському богослів'ї. Неодноразово алегорично ототожнюється зі світлом Христос у Євангелії від Іоанна, наприклад: «Я Світло для світу» [Ів. 8-12]. У православному «Символі віри» Христос визначається як «Світло від Світла» [3, с. 10]. Авторові давнього гімну вдалося створити по-справжньому величний і оригінальний образ Христа-світла, перш за все, завдяки вдалому епітету. В грецькому оригіналі гімну «фю́s í $\alpha \rho \operatorname{vó}$ » дослівно означає «світло радості», «радісне світло», однак у нашій 
традиції, починаючи зі старослов'янської версії тексту, закріпився переклад, а отже і образ Христа як «тихого» світла. Цей епітет є дуже вдалим і не поступається красою і силою оригінальному образу, адже влучно характеризує природу Христа як Боголюдини - лагідної, милостивої, тихої. «Тихим» називав Себе і Сам Христос: «Я тихий і серцем покірливий» [Мт. 11-29].

Важливо також звернути увагу на те, що українська традиція засвоїла цей образ у церковнослов'янській версії, тобто саме як «тихий світ», а не як «тихе світло». Слово «свһтъ» старослов'янською мовою означало «світло; сяйво; день; світанок; світ» [1, с. 227]. В українській мові «світ», за «Словарем української мови» Б. Грінченка, має сенси: 1) «свет, рассвет»; 2) «свет, мир, вселенная» [5, с. 108]. У сучасній мові вживання слова «світ» на означення світла сприймається як застаріле й збереглося, наприклад, у таких ідіомах, як: «ні світ ні зоря», «поки й світ сонця», «світа перед собою не бачити», «світ вгору піднявся» [6] тощо.

У Шевченка образ «тихого світу» використовується передусім у значенні «тихого світла». У вірші «Розрита могила» (1843р.) цей образ стосується понівеченої нерозумними нащадками України: «Світе тихий, краю милий, / Моя Україно!/ За що тебе сплюндровано, / За що, мамо, гинеш?» [7, с. 169]. Чільна алегорія християнського гімну - вечірне світло як Христос-Бог, переноситься Шевченком на Україну, що дозволяє тлумачити цей уривок як сакралізацію Батьківщини-матері. За допомогою образу «тихого світла» поет підносить Україну до сфери божественного - вічного, абсолютного й святого.

У посланні «І мертвим, і живим...» (1845 р.) Шевченко також пов'язує образ сакрального світла 3 долею України. Наприкінці твору поет пророкує:

І забудеться срамотня

Давняя година,

І оживе добра слава,

Слава України,

I світ ясний, невечірній

Тихо засіяє...

Обніміться ж, брати мої,

Молю вас, благаю! [7, с. 355]

У цьому уривку виразно засвідчено, що йдеться про «світ» як про «світло», але сам образ дещо видозмінений, власне, якщо говорити про епітет, - змінений на протилежний: замість тихого вечірнього світу маємо «світ ясний, невечірній». На відміну від попереднього твору тут наявний інтертекстуальний зв'язок не 3 православним гімном, а 3 
католицьким хоралом «Світ невечірній, що засяяв з висоти». Невечірнім світлом у хоралі названий Божественний Логос. Оскільки в обох творах ідеться про Христа, Шевченко контамінує ці два образи у величній пророчій метафорі: «І світ ясний, невечірній / Тихо засіяс...». Що ж означає ця метафора? Який сенс цих красивих образів?

Шевченко часто змальовував щасливе майбутнє України в координатах апокаліптичних уявлень, за допомогою образів радикально оновленої землі та Царства Божого на ній. У Шевченкових візіях благого майбуття важливе місце посідають сакральні образи Матері та Сина: «І на оновленій землі врага не буде, супостата,/А буде син, і буде мати, I будуть люде на землі» [8, с. 289]. У цьому контексті завершення послання «I мертвим, i живим...» можемо розуміти як передчуття Шевченком переродження української землі, пов'язаної з парусією - другим пришестям Сина Божого у Славі - вже не як вечірнього, а яскравого світла. У цьому полягає глибинний, богословський сенс метафори.

Найскладніша для осягнення художня інтерпретація образу «тихого світла» міститься у вірші Т. Шевченка «Світе ясний! Світе тихий!» (1860 p.):

Світе ясний! Світе тихий!

Світе вольний, несповитий!

За що ж тебе, світе-брате,

В своїй добрій, теплій хаті

Оковано, омурано

(Премудрого одурено).

Багряницями закрито

I розп'ятієм добито?

Не добито! Стрепенися!

Та над нами просвітися,

Просвітися!.. Будем, брате,

3 багряниць онучі драти,

Люльки з кадил закуряти,

Явленними піч топити,

А кропилом будем, брате,

Нову хату вимітати! [8, с. 286]

Розмаїття і конфлікт інтерпретацій навколо цього твору добре дослідила І.Даниленко [2, с. 170-173]. Найчастіше вірш приймається за «найбільш гостру антицерковну поезію не лише в українській, а й світовій поезії» [2, с. 169]. Але чи так це насправді? Ключем до тлумачення вірша $€$ апострофа - поетичне звернення до відсутньої особи, яка визначена Шевченком алегорично: «світе ясний», «світе тихий», 
«світе вольний, несповитий», «світе-брате», «премудрий», «брате». Від з'ясування, до кого саме палко звертався Шевченко, залежить розуміння суті поетових закликів.

«Тихим світом», «премудрим» і «братом» Шевченко називає Христа, про що свідчить походження чільного образу, релігійна лексика i проблематика вірша. Останнє звернення, повторене тричі, додає твору інтимної сердечності, що контрастує 3 брутальними закликами до радикальних змін. Друга визначальна алегорія вірша - це «добра, тепла хата», в якій Христа «оковано, омурано, / (Премудрого одурено), / Багряницями закрито / I розп'ятієм добито» [8, с. 286]. Річ певна, що тут йдеться про церкву, зовні величну i багату, але за своєю суттю бездуховну. Така різка оцінка - реакція Шевченка на цезаропапізм ментально чужої українцям російської церкви, що була імперським інструментом поневолення інших народів. «Візантійський Саваоф», який замінив у цій церкві тихого Христа, власне, i викликав неприйняття i запалював гнів Шевченка.

Далі поет закликає Христа стрепенутися i «просвітитися». Вкотре повторений концепт сакрального світла натякає на есхатологічне повернення Христа і Страшний суд. Подальші картини нищення церковної атрибутики, які завжди були для віруючих предметом шанобливого поклоніння, видаються до межі блюзнірськими і богохульними. Власне саме так цей уривок трактувався багатьма дослідниками [2, с. 172]. Наруга над предметами культу, зображена у вірші, в спрощеному дослівному сприйнятті приймалася за дійовий заклик, освячений генієм і авторитетом Шевченка, до реального грабунку та руйнації церкви в комуністичному суспільстві. Це вкотре переконує, що хибні інтерпретації текстів $є$ дуже небезпечними.

Цілком по-іншому зрозуміти сенс Шевченкових закликів дозволяє образ «нової хати», адже йдеться не просто про нове суспільство чи громаду, а про оновлену церкву, поява якої можлива лише після очищення старої «хати». Також під образом «нової хати» можемо розуміти оновлену після Страшного суду землю, яка сама і буде істинною церквою Христа. Таким чином ідеї вірша суголосні євангельському сюжету про очищення Христом храму від торгівців.

Парадоксально, але попри наявність у поезії «Світе ясний! Світе тихий!» закликів до нищення «святинь», вона не $\epsilon$ ані антихристиянською, ані богохульною, ані антиклерикальною. Насправді цей вірш має протиімперське спрямування, пов'язане із сатиричним викриттям iii найпотужнішого політичного інструменту - церкви без Христа. У наш час утвердження автокефалії та розбудови української церкви як духовного 
опертя нації вірш «Світе ясний! Світе тихий!» Шевченка набуває особливої актуальності та глибини.

Поезія «Світе ясний! Світе тихий!» була написана 27 червня 1860 року, за день до того - 25 червня Шевченко створив вірш-ідилію «Росли укупочці, зросли...», де змальовує щасливе сімейство і благає Бога про таку ж щасливу долю:

Подай же й нам, всещедрий Боже!

Отак цвісти, отак рости,

Так одружитися і йти,

Не сварячись в тяжкій дорозі,

На той світ тихий перейти.

Не плач, не вопль, не скрежет зуба -

Любов безвічную, сугубу

На той світ тихий принести [8, с. 285].

У цьому вірші «світ тихий» не пов'язаний з образом Христа, тут він означає потойбіччя, перебування праведного подружжя у раю. Автор цікаво переосмислює образи заупокійних молінь про відсутність у Царстві Небесному плачу та зітхань і образ пекельного скреготіння зубами. В інтерпретації Шевченка плач, зітхання, зубне скреготіння - це атрибути нещасливого сімейного життя, що їм поет протиставляє міцну любов щасливого подружжя.

Підсумовуючи, можемо стверджувати, що Шевченко найчастіше надає образу «тихий світ» значення сакрального світла, пов'язаного з особою Христа, що засвідчує прямий інтертекстуальний зв'язок Тарасових віршів 3 грецьким гімном. Маргінально наявне в Шевченковій поезії значення «тихого світу» як сакрального топосу - Царства Небесного. За допомогою образу «тихого світу» Шевченко закликає до оновлення Христової церкви, сакралізує Україну та малює іï щасливе майбуття.

\section{Література:}

1. Белей Л., Белей О. Словник старослов'янсько-український. Львів: Монастир Монахів Студитського Уставу. Видавничий відділ «Свічадо», $2001.332 \mathrm{c}$.

2. Даниленко I. Молитва як літературний жанр: генеза та еволюція. Миколаїв: Видавництво МДГУ ім. Петра Могили, 2008. 304 с.

3. Молитовник. Київ: Видавн. відділ УПЦ КП, 2006. 512 с.

4. Седакова О. Мариины слезы: К поэтике литургических песнопений. Київ: Дух і літера, 2017. 176 с.

5. Словарь української мови / Упорядкував Б. Грінченко. У 4 т. Т. 4. Київ: Наук. думка, 1997. 616 с. 
6. Словник українських ідіом / Уклав Удовиченко Г. М. Київ: Рад. письменник, 1968. 464 с.

7. Шевченко Т. Повне зібр. тв.: у 12 т. Т. 1. Київ: Наук. думка, $1991.528 \mathrm{c}$.

8. Шевченко Т. Повне зібр. тв.: у 12 т. Т. 2. Київ: Наук. думка, 1991. $592 \mathrm{c}$.

DOI https://doi.org/10.30525/978-9934-588-90-7-49

РОЗУМІННЯ ЖІНОЧОЇ ЕКЗИСТЕНЦІЇ У ТВОРАХ В. ВУЛФ І Г. ЛОУРЕНСА (НА МАТЕРІАЛІ РОМАНІВ «МІСІС ДЕЛЛОВЕЙ», «КОХАНЕЦЬ ЛЕДІ ЧАТТЕРЛЕЙ»)

\section{Чайка О. М.}

кандидат педагогічних наук,

старший викладач кафедри іноземних мов та методики викладання

Глухівський національний педагогічний університет

імені Олександра Довженка

Кушнерьова М. О.

кандидат філологічних наук,

старший викладач кафедри іноземних мов та методики викладання

Глухівський національний педагогічний університет

імені Олександра Довженка

м. Глухів, Сумська область, Украӥна

Поширення гендерних ідей у культурній свідомості європейського суспільства на початку XX ст. загострило увагу митців до проблем жіночої екзистенції. Екзистенція жінки - приховане розуміння конкретної ситуації, у якій вона існує, розуміння, яке постійно супроводжує іiі існування. Інтерес до проблем формування й існування жінки, до характеру жіночої поведінки стає провідною темою в літературі модернізму. Не залишились осторонь цієї теми й такі видатні письменники-модерністи, як Вірджинія Вулф (Virginia Woolf) і Девід Лоуренс (David Herbert Lawrence).

3 огляду на об'єктивну приналежність обох класиків англійської літератури до загальноєвропейського літературного феміністичного дискурсу спробуємо з'ясувати вузлові аспекти «жіночої» проблематики в текстах цих митців, порівняти розуміння ними екзистенції жінки. 